\title{
Power electrical network topology detection using changes of phasor measurements in transient states
}

\author{
Natalja Gotman ${ }^{1 *}$, Galina Shumilova ${ }^{1}$ \\ ${ }^{1}$ Federal Research Center "Komi Scientific Center of the Ural Branch Russian Academy of Sciences", ISE and EPN, 167000, Russia
}

\begin{abstract}
The solution of the problem of a topology detection of an electrical network on changing voltage and current phasors obtained from the phasor measurement units (PMUs) in a transient state using artificial neural networks (ANNs) is considered. Experimental results for the 14-bus test system to detect the failed line after short circuit and the line was turned on by an auto-reclosing device are presented.
\end{abstract}

\section{Introduction}

Detecting the electrical network connection diagram in real time is important for continuous monitoring of power lines to ensure uninterrupted operation of the power system. Topology changes caused, for example, by line fault, can influence other lines (leading to certain lines overload) and destabilize a whole network. The fast identification of such changes allows taking up necessary measures and for reducing the risks of cascading failures that lead to large-scale blackouts.

Various tools for monitoring electrical networks, such as SCADA (Supervisory Control and Data Acquisition), smart meters and traditional devices for measuring voltage and current have been developed and implemented. However, ensuring network observability with such unsynchronized data flows, received from these devices, remains the problem. In addition, operators can not have sufficient information about the state of the power system in real time, that is especially important when large violations occur.

The successful introduction PMUs [1] allows implementing entirely new algorithms for the power network topology detection. PMUs, unlike the traditional SCADA system, have an ability to record such fast transients with high accuracy providing synchronized measurements of current and voltage phasors from GPS/GLONASS with a high sampling rate at various geographically remote points of a power system.

Many approaches using PMU were proposed to detect topological network changes caused by line outages [2-6]. The starting point in these approaches is that the line outage causes changes of the voltage phasor (voltage magnitude and phase angle) at all buses of a power network, and these changes are larger than the variation of voltage phasor during normal operation, for example, during swings.

The key feature that makes the line outage identification possible is that voltage phasor measurements reported by PMUs are different for different line-outage scenarios, i.e., these are a kind of "signatures" that is used by authors of considered works to detect changes in the power network topology. Each method has its own specific features but in all methods detecting topology is carried out at quasi-steady-state conditions, after the end of the transient state, caused by some unforeseen circumstances, that increases the time of the line outage identification.

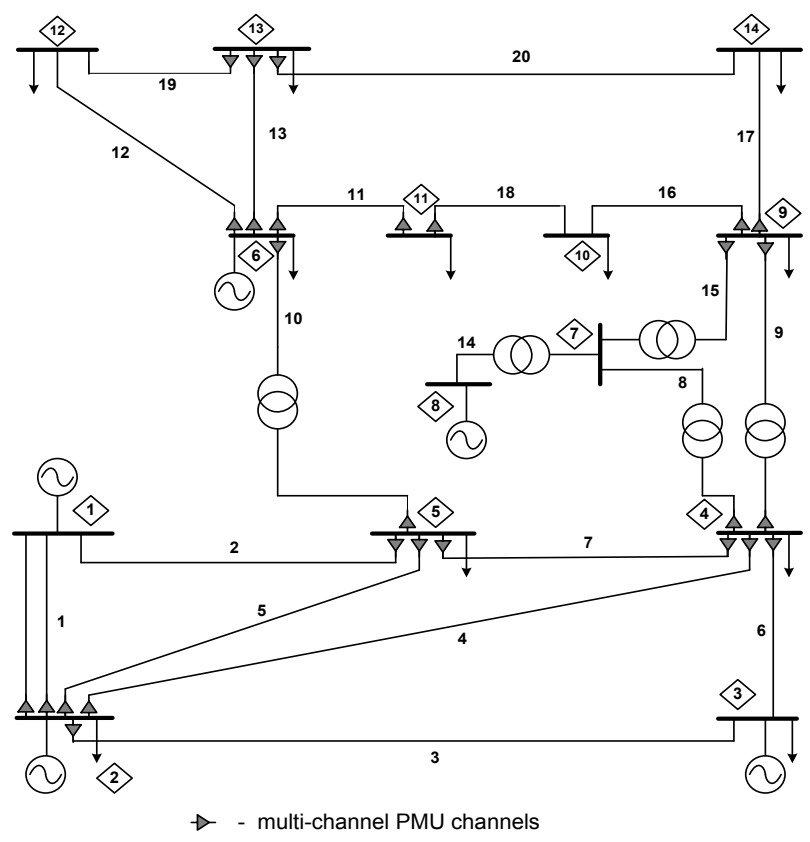

Fig. 1. 14-bus test scheme "IEEE 14 Bus Test Case" with the indicating PMU placement.

In the authors' papers [7-9], the network topology was detected using ANNs where input variables were represented by a magnitude and phase of the voltage phasor at buses at which PMUs are attached and active and reactive power flows at the end of lines near the location bus at the steady state.

\footnotetext{
* Corresponding author: gotman@energy.komisc.ru
} 
In this paper, to reduce the time necessary for detecting the line outage, it is proposed to detect the topology of a power network at the transient state and use the values of phasor measurement change reported by PMUs during the transient process. Experimental studies were carried out at the 14-bus test system. Fig. 1 shows the PMU placement at the buses 2, 4, 5, 6, 9, 11 and 13 obtained as a result of the optimal PMU deployment according to the criterion of the minimum number of devices [10] that ensure a topology observability of the power system. An observability of the bus 8 is provided due to zero injection of the transit bus 7 .

\section{ANN configuration and input parameters}

ANN configuration for the problem under consideration is shown in Fig. 2. It represents a three-layer perceptron. In the input layer of the network there are 27 neurons $N I$ (or 54, depending on the calculation option), in the output layer $-N K=15$ (the number of failed lines in the test scheme). The number of neurons in the hidden layer is defined for each case by the minimum error of the identification result.

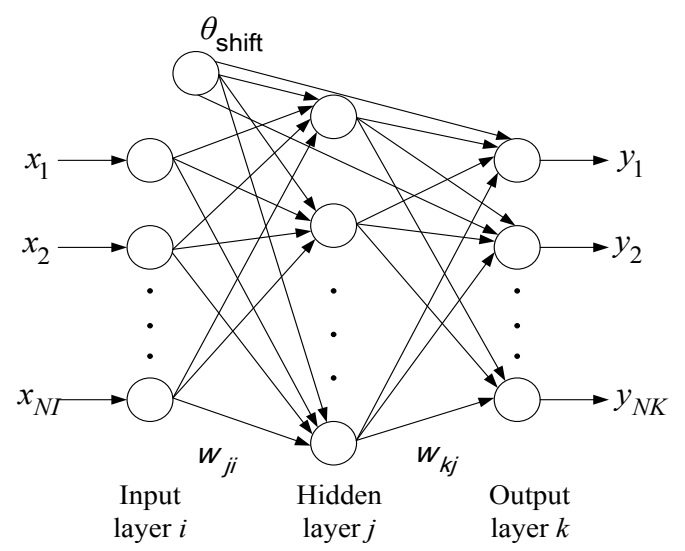

Fig. 2. Structure of the artificial neural network used to identify power network topology.

The input variables are represented by the change of a voltage phase at buses endowed with PMU and the change of a current magnitude in lines incident to buses at which PMU are attached using seven voltage phasor measurements at buses are instrumented with PMU and twenty current phasor measurements in network lines. With the above placing PMUs we get 27 phasor measurement values. When there are measurements available at both line ends, one of them could be ignored. Therefore, seven current magnitudes from 27 values were not used. Also, voltage magnitude measurements were not taken into account since most of them did not change much when there was an outage of one of the lines. The changes in the voltage phase and current magnitudes were calculated as a difference between measurement values in $0.1 \mathrm{~s}$.

\section{Experimental studies}

To obtain the data base, the calculations were carried out using program-computed complex (PCC) "RastrWin 3" ( $v$ 1.80.0.1485) which includes the program module "RUSTab" intended for the calculation of electromechanical transients. PCC "RastrWin 3" was used to simulate the 14-bus test scheme of the electrical network "IEEE 14 Bus Test Case" using data on network parameters and generators from the PCC "DigSILENT PowerFactory".

500 modes were calculated by means of the load changes in all load buses in the range of 70 - 150 percent of the base level and adding to the obtained values a random value equal to $0-20$ percent of the base load of the bus. For each mode the calculations of transients when there was an outage of one of the lines and turning on the line by an auto-reclosing device after three seconds were performed.

Given the fact that transformer outages were not considered, 15 emergencies were calculated for each of 500 modes (if transformer outages were taken into account there would be 20 emergency).

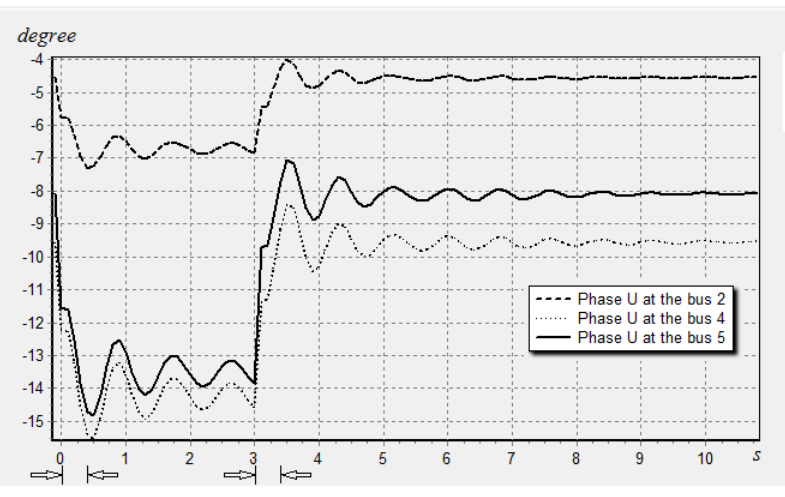

Fig. 3. Changes of the voltage phases at buses 2, 4, 5 during emergency situations for the line number 2 .

\section{Research results}

To detect the network topology with the permitted error, it is necessary to know the time period of the transient phenomena during which the neural network provides for such error. To solve this problem, calculations were carried out with two data sets. The first of them used the changes in the measurement values for one time slice with 27 input parameters of ANN. The second - the changes in measurement values for two consecutive time slices with 54 parameters.

The number of samples for ANN training and testing was varied depending on the calculation option and the number of time slices. The calculations were carried out according to the program developed in the software environment Embacadero $\mathrm{C}++$ Builder. The results are given in Table 1. For the time instants corresponding to the line outage or turning on the line by an autoreclosing device both ANNs correctly detect the network topology. 
Table 1. The comparison of the results between two calculation options of the topology detection.

\begin{tabular}{|c|c|c|c|c|c|}
\hline \multirow[b]{2}{*}{ : } & \multirow{2}{*}{ 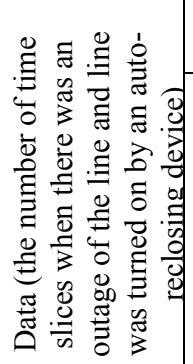 } & \multicolumn{2}{|c|}{$\begin{array}{c}\text { The number of } \\
\text { samples }\end{array}$} & \multirow{2}{*}{ 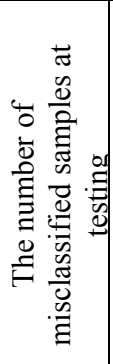 } & \multirow[b]{2}{*}{ 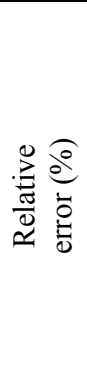 } \\
\hline & & 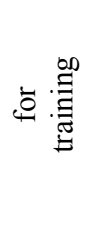 & 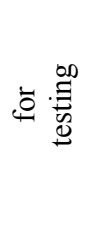 & & \\
\hline \multirow{4}{*}{ 兽 } & 1 & 6000 & 9000 & 0 & 0 \\
\hline & 2 & 12000 & 18000 & 432 & 2.4 \\
\hline & 3 & 18000 & 27000 & 1078 & 3.99 \\
\hline & 4 & 24000 & 36000 & 5616 & 15.6 \\
\hline \multirow{4}{*}{ 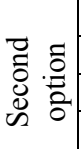 } & by 2 from 2 & 6000 & 9000 & 0 & 0 \\
\hline & by 2 from 3 & 12000 & 18000 & 358 & 1.99 \\
\hline & by 2 from 4 & 18000 & 27000 & 1185 & 4.39 \\
\hline & by 2 from 5 & 24000 & 36000 & 5914 & 16.43 \\
\hline
\end{tabular}

The results for both options are quite close to each other. The admissible relative error $4.39 \%$ for the second option corresponds to the data usage for four time slices when there was an outage of the line and four time slices when the line was turned on by an auto-reclosing device, while for the first case the relative error $15.6 \%$ corresponds to these data. On this basis one can prefer using the second version of the calculations in which the values of the changes of voltage phases and current magnitudes for two consecutive time slices are used.

Table 2 presents average values of voltage phase changes at buses are instrumented with PMUs for all modes and all emergency conditions for a time interval from $0.1 \mathrm{~s}$ to $0.5 \mathrm{~s}$ since the moment of the line outage and the moment when it is turned on by an autoreclosing device.

Table 2. Average values of change in voltage phases at the buses are instrumented with PMU when there was an outage of the line and the line was turned on by an auto-reclosing device.

\begin{tabular}{|c|c|c|c|c|c|}
\hline $\begin{array}{c}\text { Average value } \\
\text { of voltage } \\
\text { phase change } \\
\text { at the buses } \\
\text { (degrees) }\end{array}$ & 0.1 & 0.2 & 0.3 & 0.4 & 0.5 \\
\cline { 2 - 6 } & & & & & \\
\hline 2 & 0.542 & 0.167 & 0.102 & 0.071 & 0.116 \\
\hline 4 & 1.165 & 0.354 & 0.247 & 0.083 & 0.229 \\
\hline 5 & 1.027 & 0.296 & 0.208 & 0.076 & 0.186 \\
\hline 6 & 0.925 & 0.540 & 0.391 & 0.109 & 0.337 \\
\hline 9 & 1.091 & 0.491 & 0.378 & 0.111 & 0.281 \\
\hline 11 & 1.007 & 0.504 & 0.387 & 0.109 & 0.302 \\
\hline 13 & 1.043 & 0.532 & 0.393 & 0.121 & 0.334 \\
\hline
\end{tabular}

For time intervals $0.3 \mathrm{~s}$ and $0.4 \mathrm{~s}$ (the time for which the maximum admissible error for ANN with 54 parameters was obtained) the average values are in a range $[0.071 ; 0.393]$ (degrees). If one considers the value of the average change in the voltage phase at buses as a threshold of ANN application for detecting network topology, the value of 0.4 degrees can be regarded as a threshold for the studied system. That is, if the maximum change in the voltage phase among the buses with PMUs is less than the specified one, then it results in a large error of the network topology detection. The least average values correspond to an extreme points of curves of a voltage phase change. For these particular points one can observe a sharp increase in error of this solution. Fig. 3 shows the intervals of the admissible ANN calculation error when the network topology is detected (with the arrows).

\section{Conclusions}

The method of detecting electrical network topology based on ANN using phasor measurements is proposed. It is in a transient. The method allows detecting the topology at the beginning of emergency conditions associated with both line outage and turning it on by an auto-reclosing device.

Regardless of why the topology changes (line outage/turning on line) the same ANN can be used responding to changes in voltage phases and current magnitudes received from PMU.

The area for future work on this topic is the consideration of other methods for solving the problem of detecting topology in the transient phenomena as well as an inclusion of a wider range of possible events, such as generator trips, two or more lines outages.

\section{References}

1. Мокеев, А.В. Особенности разработки, испытаний и внедрения устройств синхронизированных векторных измерений // Современные подходы к обеспечению надежности электроэнергетических систем / под ред. М.В. Хохлова. Сыктывкар: Коми научный центр УрО РАН, 2014, с. 56-62.

2. Tate, J. E. Line outage detection using phasor angle measurements / J. E. Tate, T. J. Overbye // IEEE Trans. Power Syst., 2008, Vol. 23, No. 4, pp. 16441652.

3. Kim, T. PMU Placement for Line Outage Identification via Multiclass Logistic Regression / T. Kim, S.J. Wright // arXiv:1409.3832v1 [math.OC] 12 Sep 2014. pp. 1-8.

4. Cavraro, G. Power Distribution Network Topology Detection with Time-Series Signature Verification Method / G. Cavraro, R. Arghandeh // IEEE Trans. on PS, 2018, Vol. 33, No. 4, pp. 3500-3509.

5. Ponce, C. FLiER: Practical Topology Update Detection Using Sparse PMUs / C. Ponce, D. S. Bindel // IEEE Trans. Power Syst., 2017, Vol. 32, No. 6, pp. 4222-4232.

6. Srikumar, M. S. Line Outage Detection Using Phasor Measurement Units / M. S. Srikumar, Dr. T. Ananthapadmanbha, F. Z. Khan, V. Girish // Procedia Technology 21 ( 2015 ), SMART GRID Technologies, 2015, August 6-8, pp. 88 - 95.

7. Готман, Н.Э. Идентификация топологии электрической сети на основе искусственных 
нейронных сетей с использованием векторных измерений / Готман Н.Э., Шумилова Г.П., Старцева Т.Б. // Методические вопросы исследования надежности больших систем энергетики. Вып. 66. Актуальные проблемы надежности систем энергетики / под ред. Н.И. Воропая, М.А. Короткевича, А.А. Михалевича. Минск: БНТУ, 2015, с. 251-257.

8. Шумилова, Г.П. Определение топологии электрической сети при делении ее на участки с привязкой к устройствам PMU / Шумилова Г.П., Готман Н.Э., Старцева Т.Б. // Методические вопросы исследования надежности больших систем энергетики. Вып. 67. Проблемы надежности систем энергетики / под ред. Н.И. Воропая, Ю.Я. Чукреева. Сыктывкар: Издательство ООО «Коми республиканская типография», 2016, с. 250-255.
9. Готман, Н.Э. Определение топологии электрической сети с использованием синхронизированных векторных измерений / Готман Н.Э., Шумилова Г.П., Старцева Т.Б. // Актуальные проблемы, направления и механизмы развития производительных сил Севера - 2016: Материалы Пятого Всероссийского научного семинара (21-23 сентября 2016 г., Сыктывкар): в 2 ч. Сыктывкар: ООО «Коми республиканская типография», 2016, Ч. II, с. 115-123.

10. Хохлов М.В., Голуб И.И. Унифицированный подход к оптимизации размещения PMU в сети для обеспечения надежности наблюдаемости ЭЭС // Методические вопросы исследования надежности больших систем энергетики: Вып. 65. Надежность либерализованных систем энергетики / под ред. Н.И. Воропая, А.Н. Назарычева. Иркутск: ИСЭМ СО РАН, 2015, с. 591-601. 